\title{
Current Approaches to and Future Perspectives on Methomyl Degradation in Contaminated Soil/Water Environments
}

\author{
Ziqiu Lin ${ }^{1,2}$, Wenping Zhang ${ }^{1,2}$, Shimei Pang ${ }^{1,2}$, Yaohua Huang ${ }^{1,2}$, Sandhya Mishra ${ }^{1,2}$, \\ Pankaj Bhatt ${ }^{1,2} \mathbb{D}$ and Shaohua Chen $1,2, * \mathbb{C}$ \\ 1 State Key Laboratory for Conservation and Utilization of Subtropical Agro-bioresources, Guangdong \\ Province Key Laboratory of Microbial Signals and Disease Control, Integrative Microbiology Research \\ Centre, South China Agricultural University, Guangzhou 510642, China; 20192047010@stu.scau.edu.cn (Z.L.); \\ 20191047008@stu.scau.edu.cn (W.Z.); 20192047012@stu.scau.edu.cn (S.P.); \\ 20183138021@stu.scau.edu.cn (Y.H.); sandhyamanshi@gmail.com (S.M.); \\ pankajbhatt.bhatt472@gmail.com (P.B.) \\ 2 Guangdong Laboratory of Lingnan Modern Agriculture, Guangzhou 510642, China \\ * Correspondence: shchen@scau.edu.cn; Tel.: +86-20-8528-8229; Fax: +86-20-8528-0292
}

Received: 27 December 2019; Accepted: 7 February 2020; Published: 8 February 2020

\begin{abstract}
Methomyl is a broad-spectrum oxime carbamate commonly used to control arthropods, nematodes, flies, and crop pests. However, extensive use of this pesticide in agricultural practices has led to environmental toxicity and human health issues. Oxidation, incineration, adsorption, and microbial degradation methods have been developed to remove insecticidal residues from soil/water environments. Compared with physicochemical methods, biodegradation is considered to be a cost-effective and ecofriendly approach to the removal of pesticide residues. Therefore, micro-organisms have become a key component of the degradation and detoxification of methomyl through catabolic pathways and genetic determinants. Several species of methomyl-degrading bacteria have been isolated and characterized, including Paracoccus, Pseudomonas, Aminobacter, Flavobacterium, Alcaligenes, Bacillus, Serratia, Novosphingobium, and Trametes. The degradation pathways of methomyl and the fate of several metabolites have been investigated. Further in-depth studies based on molecular biology and genetics are needed to elaborate their role in the evolution of novel catabolic pathways and the microbial degradation of methomyl. In this review, we highlight the mechanism of microbial degradation of methomyl along with metabolic pathways and genes/enzymes of different genera.
\end{abstract}

Keywords: methomyl; biodegradation; physicochemical degradation; mechanism; degradation pathway

\section{Introduction}

Carbamate insecticides are commonly used in various agricultural sectors, particularly crop protection. The higher global demand for pesticides has created a market that is worth billions of dollars. Carbamates have emerged as a better substitute for organophosphorus pesticides due to their broad-spectrum efficacy and short residual period [1,2]. Methomyl (S-methyl-N-(methylcarbamoyloxy)-thioacetimide) (MET) (Figure 1), an oxime pesticide in the carbamate class, is widely used to control the eggs, larvae, and adults of different pests [3]. Methomyl inhibits acetylcholinesterase activity, causing a nerve tissue failure that kills insects [4-6]. However, long-term applications of methomyl have resulted in the development of resistance in some insects [7-9]. 
<smiles>CNC(=O)O/N=C(\C)SC</smiles>

Figure 1. The chemical structure of methomyl.

Approximately $10 \%$ of the applied pesticide reaches target organisms, and the remaining $90 \%$ is distributed in the environment where it can adversely affect non-target organisms and ecosystems [10]. Due to its high water solubility $\left(57.9 \mathrm{~g} \mathrm{~L}^{-1}, 25^{\circ} \mathrm{C}\right)$, methomyl in the environment cannot be fixed in the soil [11]. The half-life of methomyl ranges between 3 and 50 days in soil, between 6 and 262 days in water, and between 160 and 224 days in air [12-14]. Environmental residues of methomyl can affect non-target organisms through the air, water, soil, and food chain (Figure 2). Long-term exposure to methomyl can result in hepatotoxicity, cytotoxicity, and neurotoxicity in animals [15-17]. According to a survey conducted in France, $4.2 \%$ of the population was directly or indirectly poisoned with methomyl during the period 2012-2016 [18]. It has been detected in the blood, liver, kidneys, and brain of humans and animals [19-21]. Methomyl has been banned in many European countries due to its extremely high residual toxicity towards mammals, birds, and the environment [18]. Spraying, leaching, sorption, and volatilization can result in the contamination of ecosystems. Therefore, there is an urgent need to remove residual methomyl from the environment.

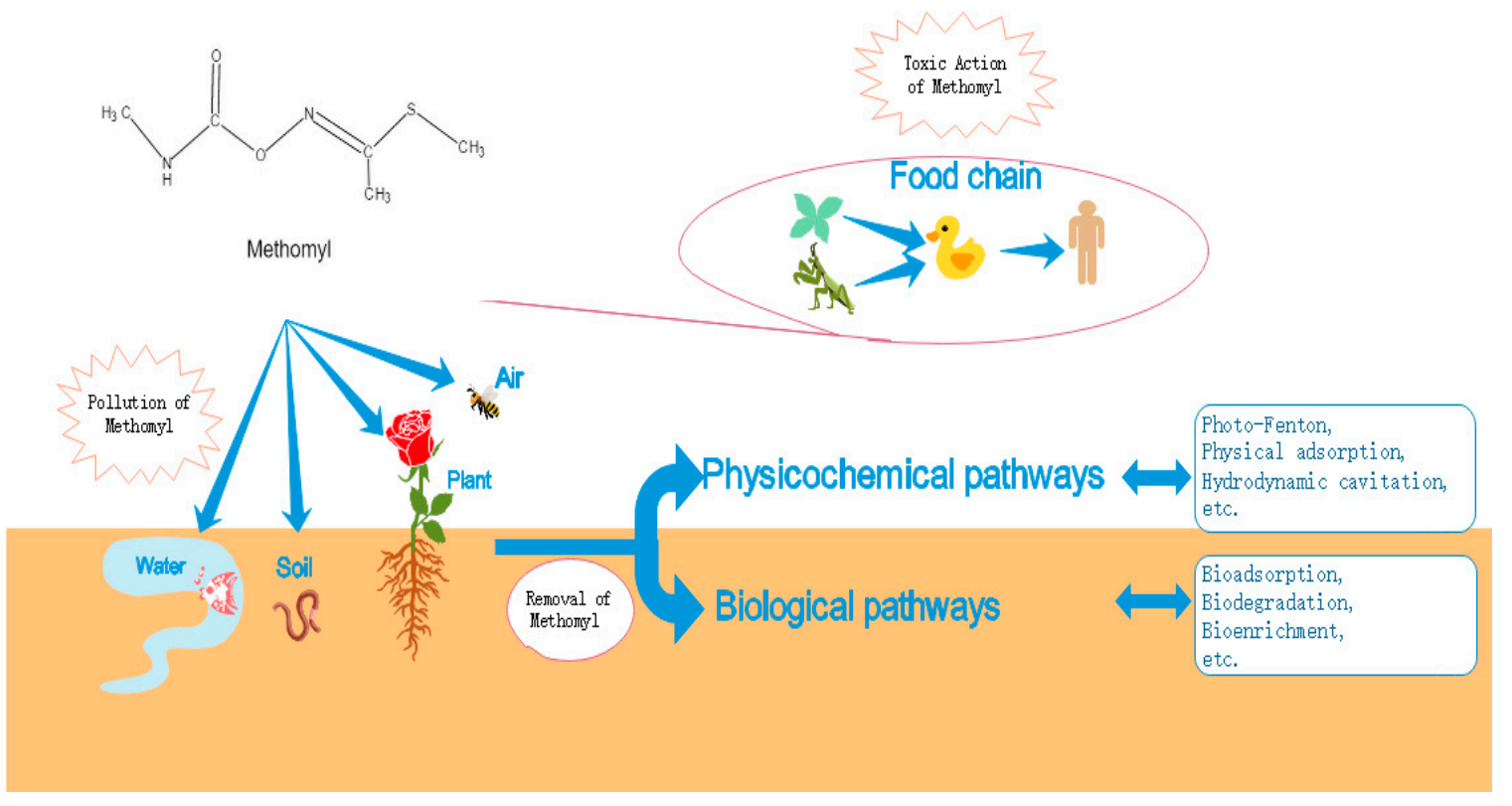

Figure 2. Contamination and removal of methomyl from soil environments.

Different degradation processes for the decontamination of methomyl-affected environments have been tested. Physicochemical methods, such as adsorption, oxidation, the Photo-Fenton process, ultrasound cavitation (US), and hydrodynamic cavitation (HC), have been studied extensively [22-24]. Microbial degradation of methomyl has emerged as a potential tool for the large-scale removal of this contaminant from the environment. A few reports focus on the isolation and characterization of methomyl-degrading micro-organisms. These microbes include Paracoccus, Pseudomonas, Aminobacter, Flavobacterium, Alcaligenes, Bacillus, Serratia, Novosphingobium, and Trametes [25-29]. Microbial degradation was found to be ecofriendly and acceptable for large-scale bioremediation of methomyl-contaminated sites [30-33]. In addition, the degradation pathways of methomyl and the fate of several metabolites have been investigated. However, there is a limited number 
of studies on methomyl-degrading enzymes and the corresponding genes in microbes. Furthermore, few reviews focus on the mechanisms and degradation pathways of methomyl. Therefore, the purpose of this review is to summarize methomyl degradation mechanisms and analyze the bioremediation potential of methomyl-degrading microbes in contaminated soil/water environments.

\section{Toxicological Effects of Methomyl Insecticides}

The chemical structure of methomyl is unstable, and it is easily decomposed in the environment. However, the use of methomyl has exceeded its natural degradation rate, leading to a cumulative effect on ecosystems and organisms [34]. The toxicological impacts of methomyl on aquatic animals, amphibians, land mammals, and humans are presented in Table 1.

Table 1. Toxicological studies of methomyl in humans and animals.

\begin{tabular}{|c|c|c|c|c|}
\hline S.No. & $\begin{array}{l}\text { Study Sample/ } \\
\text { Sample Sources }\end{array}$ & $\begin{array}{c}\text { Concentration/ } \\
\text { Volume of Methomyl }\end{array}$ & Specific Statement & References \\
\hline 1 & Tilapia & $3.2-10 \mathrm{mg} \mathrm{L}^{-1}$ & Genotoxicity caused by methomyl & [35] \\
\hline 2 & Tilapia & $0.2-200 \mu \mathrm{g} \mathrm{L}^{-1}$ & Injury to and apoptosis of testicular tissue & [36] \\
\hline 3 & Tilapia & $0.2-200 \mu \mathrm{g} \mathrm{L}^{-1}$ & Inhibition of the antioxidant system & [37] \\
\hline 4 & Tilapia & $0.2-200 \mu \mathrm{g} \mathrm{L}^{-1}$ & Disruption of the endocrine system and genetic variation & {$[38]$} \\
\hline 5 & Frogs & $8.69 \mathrm{mg} \mathrm{L}^{-1}$ & Reduced growth rates and tissue damage & [16] \\
\hline 8 & Rats & $17 \mathrm{mg} \mathrm{kg}^{-1}$ & Inhibition of the reproductive system & [40] \\
\hline 9 & Rats & $0.25-2.5 \mathrm{mg} \mathrm{kg}^{-1}$ & Inhibited activity of brain $\mathrm{ChE}$ and $\mathrm{RBC} \mathrm{ChE}$ & [41] \\
\hline 10 & Rats & $0.5-20 \mathrm{mg} \mathrm{kg}^{-1}$ & Inhibition of the reproductive system & [42] \\
\hline 11 & Rats & $10 \mathrm{mg} \mathrm{kg}^{-1}$ & Inhibition of liver function and enzyme activity & [43] \\
\hline 12 & Human & unknown & 17 people poisoned (2012-2016, France) & [18] \\
\hline 16 & Cells & $6-30 \mathrm{mmol} \mathrm{L}^{-1}$ & DNA damage and apoptosis induced by methomyl & [44] \\
\hline 17 & $\begin{array}{l}\text { Zooplankton and } \\
\text { fish }\end{array}$ & $8 \mu \mathrm{g} \mathrm{L}^{-1}$ & Reduction in the efficiency of the food chain in a $\mathrm{Cr} / \mathrm{Dg}$ system & [34] \\
\hline
\end{tabular}

Different aspects of methomyl toxicity on tilapia as a model aquatic organism have been studied $[15,35,36]$. A high concentration of methomyl was found to drastically change biochemical and histological activities in tilapia. Islamy et al. [35] reported that genotoxicity increased as the concentration of methomyl increased $\left(0-10 \mathrm{mg} \mathrm{L}^{-1}\right)$. Moreover, prolonged exposure to methomyl at a concentration above $20 \mathrm{mg} \mathrm{L}^{-1}$ can result in injury to testicular tissue [36,37]. Several studies have demonstrated that higher concentrations of methomyl might be responsible for the disruption of the endocrine system and expression of the $L H R, S t A R, 3 \beta-H S D$, and $A R \alpha$ genes in testes and the $L H \beta$ gene in the pituitary. Meng et al. [38] reported significantly reduced expressions of these genes at higher methomyl concentrations. Hazardous effects of methomyl have also been studied in frogs and toads as virulence testers and representatives of amphibians $[39,45,46]$. Short-term exposure to methomyl can severely affect the survival rate of tadpoles by causing deformations, intestinal contortions, a loss of appetite, and hyper-activation. Prolonged exposure to methomyl can cause a contortion of the spinal cord and a reduction in muscle carbohydrates [47]. Sub-lethal concentrations of methomyl can result in cell damage, an increased stress response in the liver, and repressed growth in frogs [16].

Methomyl significantly inhibits acetylcholinesterase activity in mammals and causes various health hazards related to neural, muscular, genital, intestinal, and reproductive functions. Mahgoub and El-Medany [40] reported that long-term exposure to methomyl can lead to testicular and liver damage in rats and inhibits the activity of the brain, erythrocytes (RBC), and cholinesterase (ChE). The $\mathrm{LC}_{50}$ value of methomyl for experimental rats is $20 \mathrm{mg} \mathrm{L}^{-1}$; however, daily feeding of male rats with 1.0 or $0.5 \mathrm{mg}(\mathrm{kg} \cdot \mathrm{bw})^{-1}$ of methomyl produces serious reproductive toxicity. It decreases the quality of testicles, seminal vesicles, and the prostate and sperm concentration, sexual potency, and serum testosterone levels [41,42]. 
Methomyl is highly toxic to the human body and direct or accidental exposure to high concentrations can result in severe poisoning or death $[18,48]$. Methomyl has been detected in the stomach, peripheral blood, brain, and heart of factory workers and farmers who are frequently exposed to high concentrations of methomyl. Higher concentrations of methomyl can cause death [20]. An agricultural worker reportedly died after inhaling a heavy dose of methomyl while flying a pesticide-spraying aircraft [19]. A higher concentration of methomyl has also been reported to cause cortical blindness [21]. Moreover, a large number of studies have shown that methomyl can induce DNA damage and apoptosis in HeLa cells and HEK293 cells [44].

\section{Physicochemical Methods for the Remediation of Methomyl-Affected Environments}

Physicochemical methods have been developed for the large-scale removal of methomyl from contaminated environments (Table 2). In general, these methods are effective but they are expensive to use. Overuse of methomyl can contaminate environmental matrices and exert a variety of toxic effects on humans and aquatic and terrestrial organisms. Thus, it is very important to remove residual methomyl from contaminated environments [47]. Physical adsorption and chemical degradation are the primary techniques for the degradation of pesticides. Other conventional methods for the decontamination of pesticide-polluted sites include activated carbon, $\mathrm{UV}, \mathrm{TiO}_{2}, \mathrm{H}_{2} \mathrm{O}_{2}$, and $\mathrm{O}_{3}$ adsorption [49-51]. Advanced oxidation processes (AOPs), which are formed by the combination of several oxidants, have been successfully applied to remove various pollutants from the environment [52-56]. AOPs, including the Photo-Fenton, $\mathrm{UV} / \mathrm{TiO}_{2}, \mathrm{H}_{2} \mathrm{O}_{2} / \mathrm{HC}$, and Fenton/ $\mathrm{H}_{2} \mathrm{O}_{2}$ processes, are considered to be the most efficient chemical degradation methods that consist of multiple oxidants (Figure 3) [22-24,57]. Activated carbon is an excellent substituent for the adsorption of methomyl. Cotton-stalk-activated carbon (CSAC) can adsorb $72.85 \mathrm{mg} \mathrm{g}^{-1}$ of methomyl at $25^{\circ} \mathrm{C}$ [58]. The addition of $\mathrm{O}_{2}, \mathrm{O}_{3}$, and $\mathrm{H}_{2} \mathrm{O}_{2}$ to a methomyl solution can generate hydroxyl radicals that possess a reduction capacity of $2.80 \mathrm{~V}$ and can efficiently oxidize pollutants [57]. A DSA Ti/ $\mathrm{RuO}_{2}$ electrode can degrade approximately $90 \%$ methomyl in half an hour under optimal environmental conditions [59]. Methomyl can also directly absorb UV light; however, Tamimi et al. [60] noted that UV irradiation only degraded $4 \%$ methomyl in 45 min because of the lower methomyl extinction coefficient at wavelengths higher than $290 \mathrm{~nm}$ [60]. However, the combination of UV light with other oxidants, such as in the $\mathrm{H}_{2} \mathrm{O}_{2} / \mathrm{UV}$, Fenton/UV, and $\mathrm{O}_{3} / \mathrm{UV}$ systems, significantly enhanced the degradation rate. In these systems, $\mathrm{UV}$ absorption by methomyl promotes the formation of super-strong hydroxyl radicals, in the form of $\mathrm{H}_{2} \mathrm{O}_{2}, \mathrm{Fe}(\mathrm{OH})^{2+}$, and $\mathrm{O}_{3}$, respectively, that play an important role in the oxidation of pollutants [22,61]. Sunlight or visible light can also promote the production of hydroxyl radicals by a Fenton reaction for the photocatalytic degradation of methomyl. The light-sensitive point of a Fenton reagent is as high as $600 \mathrm{~nm}$ [62]. The $\mathrm{UV} / \mathrm{TiO}_{2}$ system is the best UV-oxidant system as the absorption value of $\mathrm{TiO}_{2}$ is greater than $390 \mathrm{~nm}$ and the anatase has a band gap energy of $3.2 \mathrm{eV}[60,62]$. An addition of $\mathrm{CdSO}_{4}$ nanoparticles to a $\mathrm{UV} / \mathrm{TiO}_{2}$ system can make it more powerful [63]. 
Table 2. Physical and chemical approaches to the removal of methomyl from contaminated environments.

\begin{tabular}{|c|c|c|c|c|}
\hline S.No. & $\begin{array}{l}\text { Study Sample/ } \\
\text { Sample Sources }\end{array}$ & $\begin{array}{l}\text { Physicochemical } \\
\text { Method Used }\end{array}$ & Specific Statement & References \\
\hline 1 & $\mathrm{UV} / \mathrm{TiO}_{2}$ & Photocatalysis & $100 \%$ methomyl was degraded in $45 \mathrm{~min}$ & [60] \\
\hline 2 & Photo-Fenton & $\mathrm{AOP}_{\mathrm{S}}$ & $100 \%$ methomyl was degraded in an hour & [22] \\
\hline 3 & Fenton/Fe-ZSM-5 & Photocatalysis & Methomyl was completely degraded & [57] \\
\hline 4 & Fenton/ $\mathrm{H}_{2} \mathrm{O}_{2} / \mathrm{UV}$ & $\mathrm{AOP}_{\mathrm{S}}$ & Methomyl was degraded within $320 \mathrm{~min}$ & [43] \\
\hline 5 & Fenton/HA & Photocatalysis & HA promotes the degradation of methomyl & [64] \\
\hline 6 & Activated Carbon & Adsorption & Methomyl was removed in $2.5 \mathrm{~h}$ & [58] \\
\hline 7 & US/Photo-Fenton & $\mathrm{AOP}_{\mathrm{S}}$ & Promotion of the degradation ability & [24] \\
\hline 8 & $\mathrm{TiO}_{2}$ nanoparticles & Photocatalysis & Pesticide was removed in $1 \mathrm{~h}$ & [63] \\
\hline 9 & $\mathrm{UV} / \mathrm{TiO}_{2}$ & $\mathrm{AOP}_{\mathrm{S}}$ & Promotion of the degradation ability & [65] \\
\hline 10 & $\mathrm{HC} / \mathrm{H}_{2} \mathrm{O}_{2}$ & $\mathrm{AOP}_{\mathrm{S}}$ & Promotion of hydrodynamic cavitation & [23] \\
\hline 11 & $\mathrm{O}_{3} / \mathrm{UV}$ & $\mathrm{AOP}_{\mathrm{S}}$ & UV can promote the degradation effect & [61] \\
\hline 12 & $\mathrm{HC} /$ Fenton/O $\mathrm{O}_{3}$ & $\mathrm{AOP}_{\mathrm{S}}$ & Promotion of methomyl degradation & [66] \\
\hline 13 & DSA Ti/ $\mathrm{RuO}_{2}$ electrode & Electrocatalysis & $90 \%$ methomyl was degraded within $0.5 \mathrm{~h}$ & [59] \\
\hline
\end{tabular}

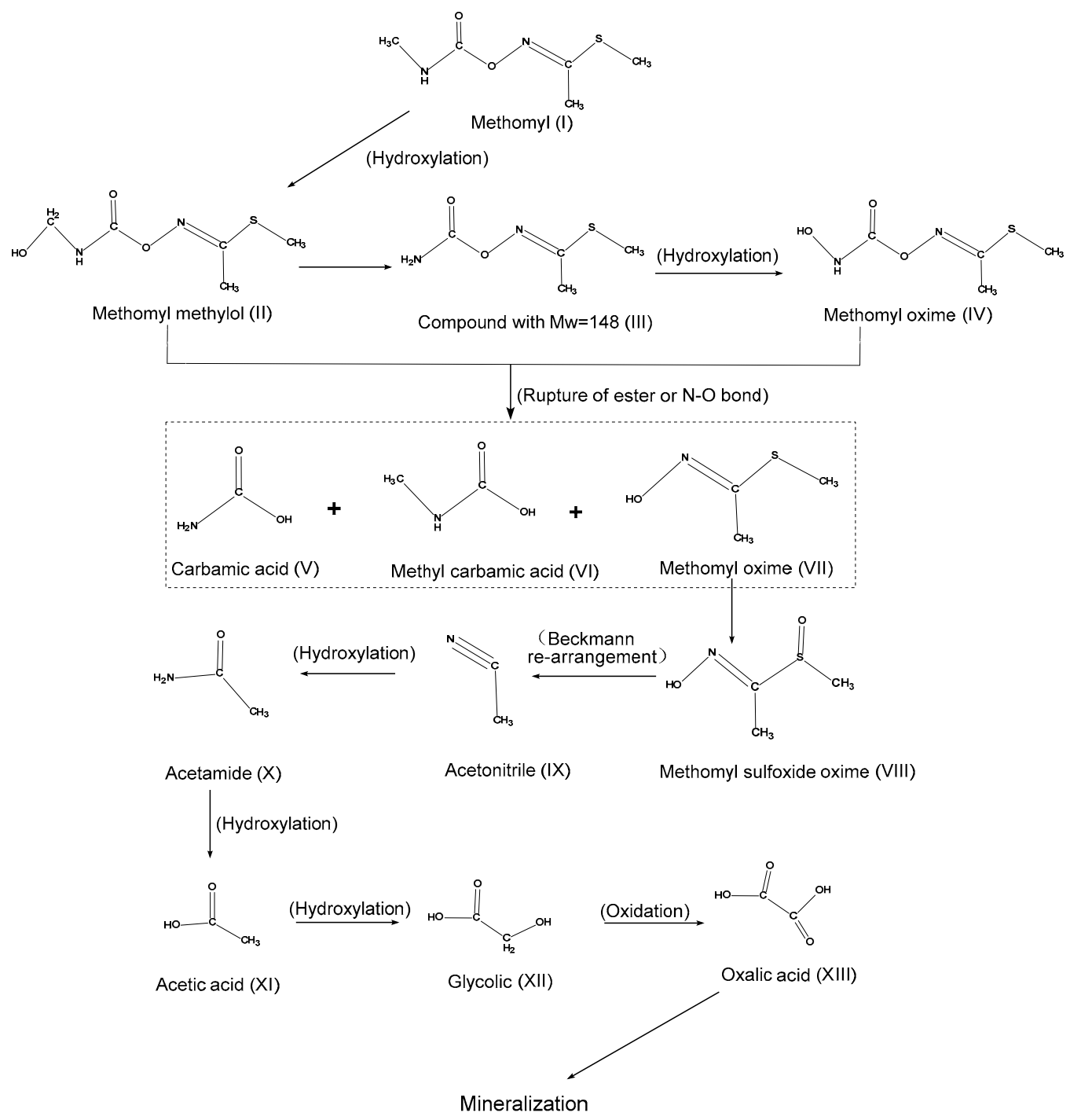

Figure 3. Methomyl degradation pathways by physicochemical methods, adapted from $[24,65]$. 
Hydroxyl radicals can effectively degrade methomyl, which is unstable and highly reactive [52]. In the Fenton $/ \mathrm{H}_{2} \mathrm{O}_{2}$ system, both $\mathrm{Fe}(\mathrm{OH})^{2+}$ and $\mathrm{H}_{2} \mathrm{O}_{2}$ can produce a large number of hydroxyl radicals by the cleavage of the molecules [43]. The addition of $\mathrm{UV}$ to this system results in photo-decarboxylation by $\mathrm{Fe}(\mathrm{OH})^{2+}$ ions that promotes the formation of hydroxyl radicals [43]. In the Fenton/Fe-ZSM-5 zeolite system, $16.22 \mathrm{mg} \mathrm{L}^{-1}$ of methomyl was completely photodegraded by $5 \mathrm{~g} \mathrm{~L}^{-1}$ of Fe-ZSM- 5 zeolite [57]. In the Fenton/humic acid (HA) system, HA promotes the catalytic generation of hydroxyl radicals by reducing $\mathrm{Fe}^{3+}$ to $\mathrm{Fe}^{2+}$ to improve the system's degradation efficiency [64].

Ultrasound (US) and hydrodynamic cavitation (HC) are new oxidation technologies that not only produce a variety of oxidizing ions, but also provide a thermal and turbulent environment with a higher efficiency than other Fenton systems [67-69]. Application of the Photo-Fenton/US system for the removal of pesticides at large scales is highly beneficial as it can reduce the cost by approximately 98 times when compared to conventional technologies [24].

These technologies can be successfully applied to the treatment of methomyl-contaminated sites. However, it is necessary to develop a treatment technology that is more feasible, ecofriendly, and easy for farmers to apply, requires less chemicals and space, and ensures that pesticides degrade completely [70]. Therefore, a more suitable and advanced degradation technology should be taken into account to increase the ecological and economical safety of the environment.

Methomyl degradation products and pathways have been explored [24,57,59]. The degradation of methomyl occurs relatively slowly under natural conditions. However, it can be completely mineralized into a harmless inorganic substance under catalytic conditions. The most important methomyl degradation pathways are hydroxylation, oxidation, and the cleavage of ester bonds, C-N bonds, and N-O bonds. Initially, methomyl (I) hydroxylates to methomyl methylol (II), which is subsequently decarboxylated to intermediate products (III). Then, a hydroxyl group replaces the $\mathrm{H}$ atom of the product (III) to form methomyl oxime (IV). Meanwhile, the cleavage of an ester bond or an N-O bond of organic matter (I, II, III, IV) produces intermediate products such as carbamic acid (V), methyl carbamic acid (VI), and methomyl oxime (VII). Product (VII) soon converts into acetonitrile (VIII) by Beckman rearrangement. Acetonitrile (VIII) finally produces $\mathrm{CO}_{2}, \mathrm{H}_{2} \mathrm{O}$, and $\mathrm{NO}_{3}{ }^{-}$after a series of oxidation reactions and a hydroxylation translation. In addition, $\mathrm{SO}_{4}{ }^{2-}$ is also produced [66].

Reactions involved in the degradation of methomyl molecules in the atmosphere, possible degradation processes, and the influence of temperature on degradation have been studied by establishing a potential energy surface [14]. Degradation of methomyl in the atmosphere was found to include an $\mathrm{H}$ atom extraction reaction and a hydroxyl radical addition reaction. These reactions took place in different groups and produced various intermediate products; however, the study could not determine the final inorganic products. Extraction reactions and addition reactions are easily affected by temperature; a rise in temperature promotes addition reactions and reduces the effectiveness of extraction reactions [14]. The addition of an Fe-zsm- 5 zeolite catalyst during the breaking of an ester bond or an $\mathrm{N}-\mathrm{O}$ bond of organic matter can also generate $\mathrm{CO}_{2}$ and $\mathrm{H}_{2} \mathrm{O}$ (I, II, III, IV). It was inferred that $\mathrm{N}$ atoms form $\mathrm{NH}_{4}{ }^{+}$and $\mathrm{NO}_{2}{ }^{-}$when removed from methomyl [57]. By comparing changes in $\mathrm{NO}_{3}{ }^{-}, \mathrm{NH}_{4}{ }^{+}$, and $\mathrm{NO}_{2}{ }^{-}$during the degradation process, another study proved that $\mathrm{NH}_{4}{ }^{+}$and $\mathrm{NO}_{2}{ }^{-}$ finally generate $\mathrm{NO}_{3}^{-}[66]$.

\section{Microbial Degradation of Methomyl}

Microbial degradation is a potential approach to the decontamination of pesticide-polluted sites. Compared with physicochemical methods, microbial degradation is considered to be a cost-effective and ecofriendly approach to the removal of pesticide residues [31-33]. Biodegrading micro-organisms, including bacteria, fungi, actinomycetes, and algae, can be obtained by enrichment cultures, genetic modification, or gene cloning [70-73]. Researchers have developed an enrichment culture technique to isolate methomyl-degrading micro-organisms from sewage treatment systems, irrigation areas, and volunteers' stool samples [28-30,74]. However, to date, only bacteria and fungi that can completely 
mineralize or degrade methomyl have been isolated and characterized, while actinomycetes and algae that can degrade methomyl have not been isolated (Table 3).

Table 3. Microbial degradation of methomyl.

\begin{tabular}{|c|c|c|c|c|c|}
\hline S.No. & Strain Or Community & Sample Source & $\begin{array}{c}\text { Detected } \\
\text { Metabolites }\end{array}$ & Comments & References \\
\hline 1 & $\begin{array}{l}\text { Mixed microbial } \\
\text { community }\end{array}$ & $\begin{array}{l}\text { Activated sludge } \\
\text { from a domestic } \\
\text { wastewater } \\
\text { treatment plant }\end{array}$ & $\begin{array}{l}\text { Methomyl } \\
\text { oxime }\end{array}$ & $\begin{array}{l}\text { Methomyl and its } \\
\text { intermediates were } \\
\text { completely degraded on } \\
\text { the 12th and the } 28 \text { th } \\
\text { day, respectively }\end{array}$ & {$[75]$} \\
\hline 2 & $\begin{array}{l}\text { Novosphingobium SP. } \\
\text { FND3 }\end{array}$ & No data & No data & $\begin{array}{c}\text { Degraded 63\% } \\
\text { methomyl within } 16 \mathrm{~h}\end{array}$ & [76] \\
\hline 3 & Paracoccus sp. YM3 & $\begin{array}{c}\text { Sludge from } \\
\text { a wastewater } \\
\text { treatment facility }\end{array}$ & No data & $\begin{array}{l}\text { Strain removed more } \\
\text { than } 80 \% \text { of methomyl } \\
\left(50 \mathrm{mg} \mathrm{L}^{-1}\right) \text { in } 7 \text { days }\end{array}$ & {$[77]$} \\
\hline 4 & $\begin{array}{c}\text { Stenotrophomonas } \\
\text { maltophilia M1 }\end{array}$ & $\begin{array}{l}\text { Irrigation sites in } \\
\text { Egypt }\end{array}$ & No data & $\begin{array}{l}\text { Bacteria can grow on } \\
\text { methomyl }\left(100 \mathrm{mg} \mathrm{L}^{-1}\right) \\
\text { and can tolerate up to } \\
1000 \mathrm{mg} \mathrm{L}^{-1} \text { of } \\
\text { methomyl in the } \\
\text { presence of } 0.05 \% \\
\text { glucose }\end{array}$ & {$[30]$} \\
\hline 5 & Paracoccus sp. mdw-1 & $\begin{array}{c}\text { Methomyl } \\
\text { wastewater } \\
\text { treatment plant }\end{array}$ & $\begin{array}{l}\text { Methomyl } \\
\text { oxime }\end{array}$ & $\begin{array}{c}100 \mathrm{mg} \mathrm{L}^{-1} \text { of methomyl } \\
\text { was transformed into } \\
\text { an unknown metabolite } \\
\text { within } 10 \mathrm{~h}\end{array}$ & [25] \\
\hline 6 & $\begin{array}{c}\text { White-rot fungal } \\
\text { isolates WR1, WR2, } \\
\text { WR4, WR9, and WR15 }\end{array}$ & $\begin{array}{l}\text { Rift-valley region } \\
\text { and a Mountain } \\
\text { region in Kenya }\end{array}$ & No data & $\begin{array}{l}\text { Complete degradation of } \\
50 \mathrm{mg} \mathrm{L}^{-1} \text { of methomyl } \\
\text { by a single strain in } 100 \\
\text { days whereas mixed } \\
\text { strains took only } 50-60 \\
\text { days }\end{array}$ & [26] \\
\hline 7 & Pseudomonas sp. EB20 & $\begin{array}{l}\text { Water polluted by } \\
\text { persistent organic } \\
\text { pollutants in Egypt }\end{array}$ & No data & $\begin{array}{c}77 \% \text { of } 10 \mathrm{mg} \mathrm{L}^{-1} \text { of } \\
\text { methomyl was degraded } \\
\text { within } 2 \text { weeks }\end{array}$ & [43] \\
\hline 8 & $\begin{array}{l}\text { Flavobacterium, } \\
\text { Alcaligenes }\end{array}$ & $\begin{array}{c}\text { Horticultural farms } \\
\text { in Rift Valley and } \\
\text { Central Kenya }\end{array}$ & No data & $\begin{array}{c}\text { Strains completely } \\
\text { degraded methomyl and } \\
\text { its metabolites within } 40 \\
\text { days as compared to the } \\
\text { control }\end{array}$ & {$[78]$} \\
\hline 9 & $\begin{array}{l}\text { A consortium of } \\
\text { Gomphonema parvulum, } \\
\text { Cymbella silesiaca, } \\
\text { and Nitzschia dissipata }\end{array}$ & Tseng-Wen River & No data & $\begin{array}{l}\text { Methomyl was } \\
\text { efficiently removed by } \\
\text { biofilms containing } \\
\text { degrading } \\
\text { micro-organisms and } \\
\text { diatoms }\end{array}$ & [79] \\
\hline 10 & Microbial communities & $\begin{array}{l}\text { Natural river } \\
\text { biofilms }\end{array}$ & No data & $\begin{array}{l}\text { 91\% of added methomyl } \\
\left(50 \mathrm{mg} \mathrm{L}^{-1}\right) \text { was } \\
\text { removed } \\
\text { in } 7 \text { days }\end{array}$ & [27] \\
\hline 11 & Pseudomonas aeruginosa & $\begin{array}{c}\text { Soil samples from } \\
\text { Dharwad }\end{array}$ & No data & $\begin{array}{c}\text { Methomyl was } \\
\text { significantly decreased }\end{array}$ & [80] \\
\hline 12 & Serratia plymuthica & $\begin{array}{c}\text { Marine coastal } \\
\text { sediment }\end{array}$ & No data & $\begin{array}{c}\text { Bacterium showed } \\
\text { an excellent ability to } \\
\text { remove imidacloprid, } \\
\text { methomyl, } \\
\text { and fenamiphos }\end{array}$ & [81] \\
\hline
\end{tabular}


Table 3. Cont.

\begin{tabular}{|c|c|c|c|c|c|}
\hline S.No. & Strain Or Community & Sample Source & $\begin{array}{c}\text { Detected } \\
\text { Metabolites }\end{array}$ & Comments & References \\
\hline 13 & $\begin{array}{c}\text { Bacillus cereus, Bacillus } \\
\text { safensis }\end{array}$ & $\begin{array}{l}\text { Pesticide-treated } \\
\text { crop field in India }\end{array}$ & No data & $\begin{array}{l}\text { B. cereus and B. safensis } \\
\text { showed } 88.25 \% \text { and } \\
77.5 \% \text { of methomyl } \\
\text { degradation, } \\
\text { respectively, within } 96 \mathrm{~h}\end{array}$ & [82] \\
\hline 14 & Pseudomonas & $\begin{array}{l}\text { Banana plantation, } \\
\text { Greece }\end{array}$ & No data & $\begin{array}{l}\text { Transformed all tested } \\
\text { carbamates including } \\
\text { aldicarb and methomyl }\end{array}$ & [83] \\
\hline 15 & $\begin{array}{c}\text { Bacillus cereus, } \\
\text { Pseudomonas aeruginosa }\end{array}$ & $\begin{array}{l}\text { Human stool } \\
\text { samples provided } \\
\text { by volunteers }\end{array}$ & $\begin{array}{l}\text { Dimethyl } \\
\text { disulfide }\end{array}$ & $\begin{array}{l}\text { Strains can generate } \\
\text { large quantities of } \\
\text { DMDS }\end{array}$ & [28] \\
\hline 16 & Trametes versicolor & No data & No data & $\begin{array}{c}\text { More than } 99 \% \\
\text { methomyl was removed } \\
\text { by the bioaugmentation } \\
\text { of the strain }\end{array}$ & [74] \\
\hline 17 & $\begin{array}{c}\text { A consortium of } \\
\text { Cupriavidus, } \\
\text { Achromobacter and } \\
\text { Pseudomonas genera }\end{array}$ & $\begin{array}{l}\text { Biopurificati-on } \\
\text { system }\end{array}$ & No data & $\begin{array}{l}\text { Methomyl was } \\
\text { completely degraded } \\
\text { within } 7 \text { days }\end{array}$ & [84] \\
\hline 18 & $\begin{array}{c}\text { Aminobacter sp. } \\
\text { MDW-2 and Afipia sp. } \\
\text { MDW-3 }\end{array}$ & $\begin{array}{l}\text { Wastewater } \\
\text { treatment system } \\
\text { of a pesticide } \\
\text { manufacturer }\end{array}$ & $\begin{array}{l}\text { Methomyl } \\
\text { oxime, methyl } \\
\text { carbamic acid }\end{array}$ & $\begin{array}{l}\text { Strains MDW-2 and } \\
\text { MDW- } 3 \text { co-existed and } \\
\text { completely degraded } 50 \\
\text { mg L }^{-1} \text { of methomyl } \\
\text { within } 3 \text { days }\end{array}$ & [29] \\
\hline 19 & $\begin{array}{l}\text { Pseudomonas putida } \\
\text { KT2440 }\end{array}$ & Genome editing & No data & $\begin{array}{c}\text { Strain simultaneously } \\
\text { degraded } \\
\text { organophosphates, } \\
\text { pyrethroids, } \\
\text { and carbamates }\end{array}$ & [85] \\
\hline 20 & Escherichia coli & India & No data & $\begin{array}{l}\text { Methomyl was } \\
\text { efficiently degraded by } \\
\text { Escherichia coli with } \\
\text { a plasmid }\end{array}$ & [86] \\
\hline 21 & $\begin{array}{c}\text { Bacillus cereus, Bacillus } \\
\text { safensis }\end{array}$ & No data & No data & $\begin{array}{c}\text { Strains degraded } \\
\text { methomyl, carbendazim, } \\
\text { and imidacloprid in NB } \\
\text { medium }\end{array}$ & [87] \\
\hline 22 & $\begin{array}{c}\text { Ascochyta sp. CBS } \\
237.37\end{array}$ & $\begin{array}{l}\text { Paddy and maize } \\
\text { cultivated fields, } \\
\text { India }\end{array}$ & No data & $\begin{array}{c}\text { Strain removed } \\
90.15 \% \text { of } 85 \mathrm{mg} \mathrm{L}^{-1} \text { of } \\
\text { carbamates in } 40 \text { days }\end{array}$ & [88] \\
\hline
\end{tabular}

It is commonly the case that a single strain can completely degrade methomyl [25]. Stenotrophomonas maltophilia M1, which was isolated from an irrigation site in Egypt, used $100 \mathrm{mg} \mathrm{L}^{-1}$ of methomyl as a carbon source and tolerated up to $1000 \mathrm{mg} \mathrm{L}^{-1}$ of methomyl in the presence of $0.05 \%$ glucose [30]. Paracoccus sp. mdw- 1 was reported to completely degrade $100 \mathrm{mg} \mathrm{L}^{-1}$ of methomyl within $10 \mathrm{~h}$ at a pH of 7.0 and $30^{\circ} \mathrm{C}$ [25]. Pseudomonas sp. EB20, which was isolated from water contaminated with persistent organic pollutants, degraded $77 \%$ of $10 \mathrm{mg} \mathrm{L}^{-1}$ of methomyl [43]. Bacillus cereus, B. safensis, Pseudomonas aeruginosa KT2440, Novosphingobium sp. FND3, and Paracoccus sp. YM3 efficiently removed $80 \%$ methomyl within 7 days as compared to the 40-day degradation period of Flavobacterium and Alcaligenes $[76,77,85,87]$. Interestingly, some bacteria can degrade methomyl as well as other pesticides, such as aldicarb, oxamyl, fenamiphos, and Imidacloprid $[75,79,84,86]$. Fungi have been proven to be potential degrading micro-organisms in nature [88,89]. Recently, fungi have received a considerable amount of attention due to their growth and extracellular enzymatic properties. Fungi not only have 
an extensive mycelium network and low specificity with respect to degrading enzymes, but also contain different enzymes, such as laccase, peroxidase, and dehydrogenase [90-92]. Phanerochaete crysosporium, which belongs to the white-rot fungal group, is one of the most effective fungal strains and can degrade a wide range of pesticides, aromatic hydrocarbons, and other xenobiotics [89,93]. Fungal bio-fortification is a method for improving the biosynthesis performance of pesticides, and Trametes versicolor was employed to efficiently degrade methomyl [74,94]. A versatile fungus, Ascochyta sp. CBS 237.37, was isolated to degrade methomyl, carbaryl, carbofuran, and carbofuran [88]. In addition, two strains of genetically engineered bacteria have also been successfully used to degrade methomyl $[85,86]$. Taking into account the contamination of the environment with various pesticides and the adaptability of indigenous micro-organisms to the environment, genetic engineering techniques may accelerate the application of degrading micro-organisms in situ.

Sometimes, single strains are not capable of complete degradation or have a weak degradation ability. In these cases, degradation can be mutually promoted by a co-culture or co-metabolism to enhance the enzyme activity. Bacteria that co-exist have a higher biodegradation ability than the individual species alone. Zhang et al. [29] isolated two bacterial strains, MDW-2 and MDW-3, from wastewater sludge samples and identified them as Aminobacter sp. and Afipia sp., respectively. Studies on their ability to degrade methomyl revealed that strain MDW-2 only accumulated intermediates and could not completely mineralize methomyl, whereas strain MDW-3 was unable to degrade methomyl. However, the combination of these two strains completely mineralized methomyl at a concentration of $50 \mathrm{mg} \mathrm{L}^{-1}$ within 3 days through co-metabolism. The five white-rot fungal strains WR1, WR2, WR4, WR9, and WR15 were isolated from horticultural soils through enrichment and screened for the ability to degrade methomyl. Degradation studies demonstrated that a single strain took 100 days to completely degrade $50 \mathrm{mg} \mathrm{L}^{-1}$ of methomyl whereas a combination of these strains completely degraded it in 50 days [26]. In addition to contaminated soil or water samples, pesticide-degrading bacteria can also be isolated from biological samples. Kawakami et al. [28] isolated Bacillus cereus, Bacillus sp., and Pseudomonas aeruginosa from human stool samples. These mixed bacterial strains possess an exceptional ability to degrade methomyl degradation and decompose it into dimethyl disulphide (DMDS) inside the human body. Roy and Das [84] achieved a microbial consortium of Cupriavidus, Achromobacter, and Pseudomonas genera, and showed that it can degrade high concentrations of carbamates, including methomyl, carbofuran, aldicarb, and methiocarb, in batch bioreactors. Methomyl can accumulate in rivers and, therefore, biofilms on the surface of rivers can produce methomyl-degrading microbes. Two microbial consortiums isolated from natural river biofilms were shown to remove methomyl or other carbamates and, thus, can be applied to purify rivers [79]. Mixed bacterial populations and microbial consortiums can also be applied in sewage treatment systems via activated sludge technology for the degradation of methomyl and its intermediates [75].

\section{Molecular Mechanism of Methomyl Degradation}

Methomyl degradation is linked to the genetic structure of micro-organisms. Each methomyl-degrading micro-organism has functional genes encoding for the enzymes that play a direct role in methomyl degradation. These enzymes can convert each metabolite into a nontoxic intermediate. Under adverse conditions, microbes benefit from methomyl as a source of nutrition. Previous studies have found that an enzymatic degradation system is more effective than the direct use of micro-organisms [95-101]. Genes and enzymes involved in the development of drugs have been investigated [102-104]. However, there are only a few studies on the enzymatic degradation pathway of methomyl.

Plasmids determine the degradation effect of bacteria and facilitate their study at the molecular level [105-109]. The PMb plasmid (5 KB) was isolated from Stenotrophomonas maltophilia M1 and screened for the ability to degrade methomyl via transformation into Escherichia coli [30]. Kulkarni and Kaliwal [86] isolated a plasmid from E. coli that can efficiently degrade methomyl. Furthermore, a carbamate-hydrolase gene cehA was isolated from Pseudomonas that controls the degradation of 
methomyl. Kulkarni and Kaliwal [80] also found that the plasmid of Pseudomonas aeruginosa controls the degradation of methomyl and can be used as a cloning vehicle in recombinant DNA technology. Another methomyl-degrading E. coli plasmid was isolated from the main chromosome [86]. Catalase and cytochrome oxidase were isolated from flavobacteria and alkaline bacteria, respectively; however, further studies on these degradation products were not carried out [83].

Methomyl biodegradation pathways are presented in Figure 4. The methomyl degradation process includes hydroxylation, oxidation, and the cleavage of ester, C-N, C-S, and N-O bonds. Cleavage of an ester bond leads to the production of methyl carbamic acid (iii) and methomyl oxime (iv), which are catalyzed by carboxylesterase [83]. Then, methyl carbamic acid (iii) will be broken down into formic acid (v) and methylamine (vi), because amidases will attack the $\mathrm{C}-\mathrm{N}$ bonds. Finally, formic acid (v) generates $\mathrm{CO}_{2}$, and methylamine (vi) is degraded into formaldehyde and other minerals by methylamine dehydrogenase [83]. Fungal degradation of methomyl produces dimethyl disulfide (DMDS) (ii) through the cleavage of C-S bonds [28]. Degradative plasmids also play an important role in degradation studies of various pesticides. Unlike the physicochemical degradation pathways, dimethyl disulfide (ii) is formed during fungal biodegradation.

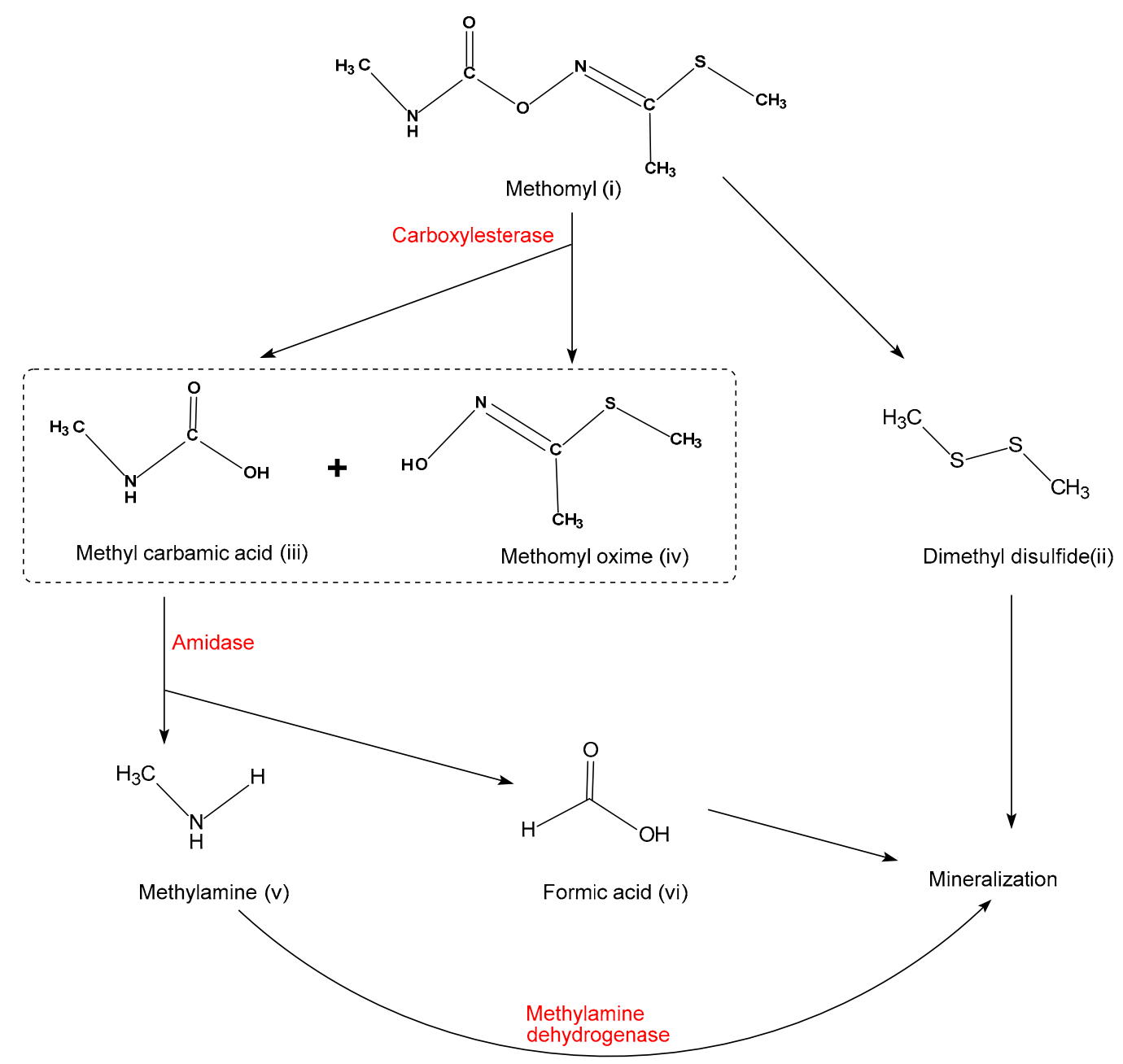

Figure 4. Proposed microbial degradation pathways of methomyl, adapted from [28,29,83].

However, more focused research is needed to culture and identify micro-organisms with potent catabolic genes and enzymes and explore novel metabolic pathways that can act on a variety of pesticides. 


\section{Conclusions and Future Perspectives}

Methomyl plays a very important role in modern agricultural practices, but its toxicity has raised widespread concern. Recently, different physicochemical methods have been developed for the removal of methomyl from contaminated environments, but they are expensive to use and generate toxic intermediate products. Thus, microbial degradation of methomyl is considered to be the most effective method. A few methomyl-degrading bacteria have been isolated, including Paracoccus, Pseudomonas, and Aminobacter. However, methomyl degradation pathways and related degradative enzymes and functional genes have not been thoroughly explored. Therefore, advanced molecular techniques, such as metagenomics, proteomics, and transcriptomics, should be developed to perform a genetic analysis of methomyl-degrading enzymes and catabolic genes, missing links, and degradation evolution mechanisms and pathways. A better understanding of the detoxification pathways in non-target species may help us to design safer and more specific carbamate insecticides. Natural micro-organisms lack the ability to simultaneously degrade different types of pesticides; however, synthetic biology offers powerful tools to create multifunctional biodegrading micro-organisms for in situ bioremediation. In the future, genetically engineered micro-organisms for methomyl degradation and related genes and enzymes should be explored in depth. DNA stable isotope probing techniques can be used to assess which organisms are degrading methomyl in situ, as the indigenous organisms may be better adapted than isolates.

Author Contributions: Conceptualization: S.C.; data analysis: Z.L., W.Z., and S.P.; writing—original draft preparation: Z.L.; writing-review and editing: W.Z., S.P., Y.H., S.M., P.B., and S.C.; supervision, funding acquisition, and project administration: S.C. All authors have read and agreed to the published version of the manuscript.

Funding: This research was funded by Key-Area Research and Development Program of Guangdong Province (2018B020206001), National Natural Science Foundation of China (31401763), and Guangdong Special Branch Plan for Young Talent with Scientific and Technological Innovation (2017TQ04N026).

Conflicts of Interest: The authors declare no conflict of interest. The funders had no role in the design of the study; in the collection, analyses, or interpretation of data; in the writing of the manuscript, or in the decision to publish the results.

\section{References}

1. Ribera, D.; Narbonne, J.F.; Arnaud, C.; Saint-Denis, M. Biochemical responses of the earthworm Eisenia fetida andrei exposed to contaminated articial soil, effects of carbaryl. Soil Biol. Biochem. 2001, 33, 1123-1130. [CrossRef]

2. Kaur, M.; Sandhir, R. Comparative effects of acute and chronic carbofuran exposure on oxidative stress and drug-metabolizing enzymes in liver. Drug Chem. Toxicol. 2008, 29, 415-421. [CrossRef]

3. Fernandez-Alba, A.R.; Hernando, D.; Aguera, A.; Caceres, J.; Malato, S. Toxicity assays: A way for evaluating AOPs efficiency. Water Res. 2002, 36, 4255-4262. [CrossRef]

4. Filho, M.V.S.; Oliveira, M.M.; Salles, J.B.; Bastos, V.L.F.C.; Cassano, V.P.F.; Bastos, J.C. Methyl-paraoxon comparative inhibition kinetics for acetylcholinesterases from brain of neotropical fishes. Toxicol. Lett. 2004, 153, 247-254. [CrossRef]

5. Yi, M.; Liu, H.; Shi, X.; Liang, P.; Gao, X. Inhibitory effects of four carbamate insecticides on acetylcholinesterase of male and female Carassius auratus in vitro. Comp. Biochem. Phys. C 2006, 143, 113-116. [CrossRef]

6. Ren, Q.; Zhao, R.; Wang, C.; Li, S.; Zhang, T.; Ren, Z.; Yang, M.; Pan, H.; Xu, S.; Zhu, J.; et al. The role of AChE in swimming behavior of Daphnia magna: Correlation analysis of both parameters affected by deltamethrin and methomyl exposure. J. Toxicol. 2017, 2017, 3265727. [CrossRef]

7. Abbas, N.; Shad, S.A. Assessment of resistance risk to lambda-cyhalothrin and cross-resistance to four other insecticides in the house fly, Musca domestica L. (Diptera: Muscidae). Parasitol. Res. 2015, 114, 2629-2637. [CrossRef] [PubMed]

8. Mutunga, J.M.; Anderson, T.D.; Craft, D.T.; Gross, A.D.; Swale, D.R.; Tong, F.; Wong, D.W.; Carlier, P.R.; Bloomquist, J.R. Carbamate and pyrethroid resistance in the akron strain of Anopheles gambiae. Pestic. Biochem. Phys. 2015, 121, 116-121. [CrossRef] [PubMed] 
9. Ibrahim, S.S.; Ndula, M.; Riveron, J.M.; Irving, H.; Wondji, C.S. The P450 CYP6Z1 confers carbamate/pyrethroid cross-resistance in a major African malaria vector beside a novel carbamate-insensitive N485I acetylcholinesterase-1 mutation. Mol. Ecol. 2016, 25, 3436-3452. [CrossRef] [PubMed]

10. Selvam, A.; Gnana, D.; Thatheyu, A.J.; Vidhya, R. Biodegradation of the synthetic pyrethroid, fenvalerate by Bacillus cereus Mtcc 1305. World J. Environ. Eng. 2013, 1, 21-26.

11. Malato, S.; Blanco, J.; Cáceres, J.; Fernández-Alba, A.R.; Agüera, A.; Rodríguez, A. Photocatalytic treatment of water-soluble pesticides by photo-Fenton and $\mathrm{TiO}_{2}$ using solar energy. Catal. Today. 2002, 76, 209-220. [CrossRef]

12. Yang, G.; Zhao, Y.; Lu, X.; Gao, X. Adsorption of methomyl on marine sediments. Colloids Surf. A Physicochem. Eng. Asp. 2005, 264, 179-186. [CrossRef]

13. Van Scoy, A.R.; Yue, M.; Deng, X.; Tjeerdema, R.S. Environmental fate and toxicology of methomyl. Rev. Environ. Contam. Toxicol. 2013, 222, 93-109. [PubMed]

14. Wu, X.; Sun, X.; Zhang, C.; Gong, C.; Hu, J. Micro-mechanism and rate constants for OH-initiated degradation of methomyl in atmosphere. Chemosphere 2014, 107, 331-335. [CrossRef]

15. Meng, S.; Qiu, L.; Hu, G.; Fan, L.; Song, C.; Zheng, Y.; Wu, W.; Qu, J.; Li, D.; Chen, J.; et al. Effect of methomyl on sex steroid hormone and vitellogenin levels in serum of male tilapia (Oreochromis niloticus) and recovery pattern. Environ. Toxicol. 2017, 32, 1869-1877. [CrossRef]

16. Waret, T.; Supap, S.; Kanokporn, S.; Monruedee, C. Lethal and sublethal effects of a methomyl-based insecticide in Hoplobatrachus rugulosus. J. Toxicol. Pathol. 2017, 30, 15-24.

17. Seleem, A.A. Induction of hyperpigmentation and heat shock protein 70 response to the toxicity of methomyl insecticide during the organ development of the Arabian toad, Bufo arabicus (Heyden, 1827). J. Histotechnol. 2019, 42, 104-115. [CrossRef]

18. Boucaud-Maitre, D.; Rambourg, M.; Sinno-Tellier, S.; Puskarczyk, E.; Pineau, X.; Kammerer, M.; Bloch, J.; Langrand, J. Human exposure to banned pesticides reported to the French Poison Control Centers: 2012-2016. Environ. Toxicol. Pharmacol. 2019, 69, 51-56. [CrossRef]

19. Driskell, W.J.; Groce, D.F.; Hill, J.R.H. Methomyl in the blood of a pilot who crashed during aerial spraying. J. Anal. Toxicol. 1991, 15, 339-340. [CrossRef]

20. Hoizey, G.; Canas, F.; Binet, L.; Kaltenbach, M.L.; Jeunehomme, G.; Bernard, M.; Lamiable, D. Thiodicarb and methomyl tissue distribution in a fatal multiple compounds poisoning. J. Forensic Sci. 2008, 53, 499-502. [CrossRef]

21. Lin, C. Methomyl poisoning presenting with decorticate posture and cortical blindness. Neurol. Int. 2014, 6, 5307. [CrossRef] [PubMed]

22. Tamimi, M.; Qourzal, S.; Barka, N.; Assabbane, A.; AitichouI, Y. Methomyl degradation in aqueous solutions by Fenton's reagent and the photo-Fenton system. Sep. Purif. Technol. 2008, 61, 103-108. [CrossRef]

23. Sayyaadi, H. Enhanced cavitation-oxidation process of non-VOC aqueous solution using hydrodynamic cavitation reactor. Chem. Eng. J. 2015, 272, 79-91. [CrossRef]

24. Raut-Jadhav, S.; Saini, D.; Sonawane, S.; Pandit, A. Effect of process intensifying parameters on the hydrodynamic cavitation based degradation of commercial pesticide (methomyl) in the aqueous solution. Ultrason. Sonochem. 2016, 28, 283-293. [CrossRef] [PubMed]

25. Xu, J.; Wu, J.; Wang, Z.; Wang, K.; Li, M.; Jiang, J.; He, J.; Li, S. Isolation and characterization of a methomyl-degrading Paracoccus sp. mdw-1. Pedosphere. 2009, 2, 238-243. [CrossRef]

26. Nyakundi, W.O.; Magoma, G.; Ochora, J.; Nyende, A.B. Biodegradation of diazinon and methomyl pesticides by white rot fungi from selected horticultural farms in rift valley and central Kenya. J. Appl. Tech. Environ. Sanit. 2012, 1, 107-124.

27. Chen, C.; Wu, T.; Wang, H.; Wu, S.; Tien, C. The ability of immobilized bacterial consortia and strains from river biofilms to degrade the carbamate pesticide methomyl. Int. J. Environ. Sci. Technol. 2015, 12, 2857-2866. [CrossRef]

28. Kawakami, Y.; Fuke, C.; Fukasawa, M.; Ninomiya, K.; Ihama, Y.; Miyazaki, T. An experimental study of postmortem decomposition of methomyl in blood. Legal Med. Tokyo. 2017, 25, 36-42. [CrossRef]

29. Zhang, C.; Yang, Z.; Jin, W.; Wang, X.; Zhang, Y.; Zhu, S.; Yu, X.; Hu, G.; Hong, Q. Degradation of methomyl by the combination of Aminobacter sp. MDW-2 and Afipia sp. MDW-3. Lett. Appl. Microbiol. 2017, 64, $289-296$. [CrossRef] 
30. Mohamed, M.S. Degradation of methomyl by the novel bacterial strain Stenotrophomonas maltophilia M1. Electron. J. Biotechn. 2009, 12, 6-7. [CrossRef]

31. Zhan, H.; Feng, Y.; Fan, X.; Chen, S. Recent advances in glyphosate biodegradation. Appl. Microbiol. Biotechnol. 2018, 102, 5033-5043. [CrossRef] [PubMed]

32. Bhatt, P.; Huang, Y.; Zhan, H.; Chen, S. Insight into microbial applications for the biodegradation of pyrethroid insecticides. Front. Microbiol. 2019, 10, 1778. [CrossRef] [PubMed]

33. Huang, Y.; Zhan, H.; Bhatt, P.; Chen, S. Paraquat degradation from contaminated environments: Current achievements and perspectives. Front. Microbiol. 2019, 10, 1754. [CrossRef] [PubMed]

34. Mano, H.; Tanaka, Y. Mechanisms of compensatory dynamics in zooplankton and maintenance of food chain efficiency under toxicant stress. Ecotoxicology 2016, 25, 399-411. [CrossRef]

35. Islamy, R.A.; Yanuhar, U.; Hertika, A.M.S. Assessing the Genotoxic Potentials of Methomyl-based Pesticide in Tilapia (Oreochromis niloticus) Using Micronucleus Assay. J. Exp. Life Sci. 2017, 7, 88-93. [CrossRef]

36. Meng, S.; Liu, T.; Chen, X.; Qiu, L.; Hu, G.; Song, C.; Xu, P. Effect of chronic exposure to methomyl on tissue damage and apoptosis in testis of tilapia (Oreochromis niloticus) and recovery pattern. Bull. Environ. Contam. Toxicol. 2019, 102, 371-376. [CrossRef]

37. Meng, S.; Chen, J.; Hu, G.; Song, C.; Fan, L.; Qiu, L.; Xu, P. Effects of chronic exposure of methomyl on the antioxidant system in liver of Nile tilapia (Oreochromis niloticus). Ecotoxicol. Environ. Saf. 2014, 101, 1-6. [CrossRef]

38. Meng, S.; Qiu, L.; Hu, G.; Fan, L.; Song, C.; Zheng, Y. Effects of methomyl on steroidogenic gene transcription of the hypothalamic-pituitary-gonad-liver axis in male tilapia. Chemosphere 2016, 165, 152-162. [CrossRef]

39. Lau, E.T.; Karraker, N.E.; Leung, K.M. Temperature-dependent acute toxicity of methomyl pesticide on larvae of 3 Asian amphibian species. Environ. Toxicol. Chem. 2015, 34, 2322-2327. [CrossRef]

40. Mahgoub, A.A.; El-Medany, A.H. Evaluation of chronic exposure of the male rat reproductive system to the insecticide methomyl. Pharmacol. Res. 2001, 44, 73-80. [CrossRef]

41. Moser, V.C.; Phillips, P.M.; McDaniel, K.L. Assessment of biochemical and behavioral effects of carbaryl and methomyl in Brown-Norway rats from preweaning to senescence. Toxicology 2015, 331, 1-13. [CrossRef] [PubMed]

42. Shalaby, M.A.; El Zorba, H.Y.; Ziada, R.M. Reproductive toxicity of methomyl insecticide in male rats and protective effect of folic acid. Food Chem. Toxicol. 2010, 48, 3221-3226. [CrossRef] [PubMed]

43. El-Fakharany, I.I.; Massoud, A.H.; Derbalah, A.S.; Allah, M.S.S. Toxicological effects of methomyl and remediation technologies of its residues in an aquatic system. J. Environ. Chem. Ecotoxicol. 2011, 3, 332-339.

44. Xiang, G.; Li, D.; Yuan, J.; Guan, J.; Zhai, H.; Shi, M.; Tao, L. Carbamate insecticide methomyl confers cytotoxicity through DNA damage induction. Food Chem. Toxicol. 2013, 53, 352-358.

45. Pantani, C.; Pannunzio, G.; De Cristofaro, M.; Novelli, A.A.; Salvatori, M. Comparative acute toxicity of some pesticides, metals, and surfactants to Gammarus italicus Goedm and Echinogammarus tibaldii pink and stock (Crustacea: Amphipoda). Bull. Environ. Contam. Toxicol. 1997, 59, 963-967. [CrossRef]

46. Bridges, C.M. Long-term effects of pesticide exposure at various life stages of the southern leopard frog (Rana sphenocephala). Arch. Environ. Contam. Toxicol. 2000, 39, 91-96. [CrossRef]

47. Seleem, A.A. Teratogenicity and neurotoxicity effects induced by methomyl insecticide on the developmental stages of Bufo arabicus. Neurotoxicol. Teratol. 2019, 72, 1-9. [CrossRef]

48. Tsatsakis, A.M.; Tsakalof, A.K.; Siatitsas, Y.; Michalodimitrakis, E.N. Acute poisoning with carbamate pesticides: The Cretan experience. Sci. Justice 1996, 36, 35-39. [CrossRef]

49. Sieliechi, J.M.; Thue, P.S. Removal of paraquat from drinking water by activated carbon prepared from waste wood. Desalin. Water Treat. 2014, 4, 986-998. [CrossRef]

50. Zhao, Y.; Wang, L.; Yu, H.; Jiang, B.; Jiang, J. Comparison of sludge treatment by $\mathrm{O}_{3}$ and $\mathrm{O}_{3} / \mathrm{H}_{2} \mathrm{O}_{2}$. Water Sci. Technol. 2014, 70, 114-119.

51. Pan, X.; Chen, $\mathrm{X}$.; Yi, Z. Defective, Porous $\mathrm{TiO}_{2}$ nanosheets with Pt decoration as an efficient photocatalyst for ethylene oxidation synthesized by a $\mathrm{C}_{3} \mathrm{~N}_{4}$ templating method. ACS Appl. Mater. Interfaces 2016, 8, 10104-10108. [CrossRef] [PubMed]

52. Esplugas, S.; Giménez, J.; Contreras, S.; Pascual, E.; Rodríguez, M. Comparison of different advanced oxidation processes for phenol degradation. Water Res. 2002, 36, 1034-1042. [CrossRef]

53. Micó, M.M.; Bacardit, J.; Malfeito, J.; Sans, C. Enhancement of pesticide photo-Fenton oxidation at high salinities. Appl. Catal. B Environ. 2013, 132, 162-169. [CrossRef] 
54. Gao, Z.; Lin, Y.; Xu, B.; Pan, Y.; Xia, S.; Gao, N.; Zhang, T.; Chen, M. Degradation of acrylamide by the $\mathrm{UV} /$ chlorine advanced oxidation process. Chemosphere 2017, 187, 268-276. [CrossRef] [PubMed]

55. Javier Benitez, F.; Real, F.J.; Acero, J.L.; Casas, F. Assessment of the UV/Cl 2 advanced oxidation process for the degradation of the emerging contaminants amitriptyline hydrochloride, methyl salicylate and 2-phenoxyethanol in water systems. Environ. Technol. 2017, 38, 2508-2516. [CrossRef] [PubMed]

56. Wardenier, N.; Liu, Z.; Nikiforov, A.; Van Hulle, S.W.H.; Leys, C. Micropollutant elimination by $\mathrm{O}_{3}$, UV and plasma-based AOPs: An evaluation of treatment and energy costs. Chemosphere 2019, 234, 715-724. [CrossRef]

57. Tomašević, A.; Kiss, E.; Petrović, S.; Mijin, D. Study on the photocatalytic degradation of insecticide methomyl in water. Desalination 2010, 262, 228-234. [CrossRef]

58. El-Geundi, M.S.; Nassar, M.M.; Farrag, T.E.; Ahmed, M.H. Methomyl adsorption onto cotton stalks activated carbon (csac): Equilibrium and process design. Procedia Environ. Sci. 2013, 17, 630-639. [CrossRef]

59. Grgur, B.N.; Mijin, D. A kinetics study of the methomyl electrochemical degradation in the chloride containing solutions. Appl. Catal. B Environ. 2014, 147, 429-438. [CrossRef]

60. Tamimi, M.; Qourzal, S.; Assabbane, A.; Chovelon, J.M.; Ferronato, C.; Ait-Ichou, Y. Photocatalytic degradation of pesticide methomyl: Determination of the reaction pathway and identification of intermediate products. Photochem. Photobio. Sci. 2006, 5, 477. [CrossRef]

61. Chang, C.; Trinh, C.; Chiu, C.; Chang, C.; Chiang, S.; Ji, D.; Tseng, J.; Chang, C.; Chen, Y. UV-C irradiation enhanced ozonation for the treatment of hazardous insecticide methomyl. J. Taiwan Inst. Chem. Eng. 2015, 49, 100-104. [CrossRef]

62. Malato, S.; Blanco, J.; Vidal, A.; Richter, C. Photocatalysis with solar energy at a pilot-plant scale: An overview. Appl. Catal. B Environ. 2002, 37, 1-15. [CrossRef]

63. Barakat, N.A.M.; Nassar, M.M.; Farrag, T.E.; Mahmoud, M.S. Effective photodegradation of methomyl pesticide in concentrated solutions by novel enhancement of the photocatalytic activity of $\mathrm{TiO}_{2}$ using $\mathrm{CdSO}_{4}$ nanoparticles. Environ. Sci. Pollut. Res. 2014, 21, 1425-1435. [CrossRef]

64. Fan, C.; Horng, C.; Li, S. Structural characterization of natural organic matter and its impact on methomyl removal efficiency in Fenton process. Chemosphere 2013, 93, 178-183. [CrossRef]

65. Juang, R.; Chen, C. Comparative study on photocatalytic degradation of methomyl and parathion over UV-irradiated $\mathrm{TiO}_{2}$ particles in aqueous solutions. J. Taiwan Inst. Chem. E 2014, 45, 989-995. [CrossRef]

66. Raut-Jadhav, S.; Pinjari, D.V.; Saini, D.R.; Sonawane, S.H.; Pandit, A.B. Intensification of degradation of methomyl (carbamate group pesticide) by using the combination of ultrasonic cavitation and process intensifying additives. Ultrason. Sonochem. 2016, 31, 135-142. [CrossRef]

67. Gogate, P.R. Treatment of wastewater streams containing phenolic compounds using hybrid techniques based on cavitation: A review of the current status and the way forward. Ultrason. Sonochem. 2008, 15, 1-15. [CrossRef]

68. Sutkar, V.S.; Gogate, P.R. Design aspects of sonochemical reactors: Techniques for understanding cavitational activity distribution and effect of operating parameters. Chem. Eng. J. 2009, 155, 26-36. [CrossRef]

69. Villaroel, E.; Silva-Agredo, J.; Petrier, C.; Taborda, G.; Torres-Palma, R.A. Ultrasonic degradation of acetaminophen in water: Effect of sonochemical parameters and water matrix. Ultrason. Sonochem. 2014, 21, 1763-1769. [CrossRef]

70. Chen, S.; Chang, C.; Deng, Y.; An, S.; Dong, Y.; Zhou, J.; Hu, M.; Zhong, G.; Zhang, L. Fenpropathrin biodegradation pathway in Bacillus sp. DG-02 and its potential for bioremediation of pyrethroid-contaminated soils. J. Agric. Food Chem. 2014, 62, 2147-2157. [CrossRef]

71. Birolli, W.G.; Alvarenga, N.; Seleghim, M.H.R.; Porto, A.L.M. Biodegradation of the pyrethroid pesticide esfenvalerate by marine-derived fungi. Mar. Biotechnol. 2016, 18, 511-520. [CrossRef]

72. Chen, S.; Yang, L.; Hu, M.; Liu, J. Biodegradation of fenvalerate and 3-phenoxybenzoic acid by a novel Stenotrophomonas sp. strain ZS-S-01 and its use in bioremediation of contaminated soils. Appl. Microbiol. Biotechnol. 2011, 90, 755-767. [CrossRef]

73. Zhan, H.; Wang, H.; Liao, L.; Feng, Y.; Fan, X.; Zhang, L.H.; Chen, S. Kinetics and novel degradation pathway of permethrin in Acinetobacter baumannii ZH-14. Front. Microbiol. 2018, 9, 98. [CrossRef]

74. Rodríguez-Rodríguez, C.E.; Madrigal-León, K.; Masís-Mora, M.; Pérez-Villanueva, M.; Chin-Pampillo, J.S. Removal of carbamates and detoxification potential in a biomixture: Fungal bioaugmentation versus traditional use. Ecotoxicol. Environ. Saf. 2017, 135, 252-258. [CrossRef] [PubMed] 
75. Farré, M.; Fernandez, J.; Paez, M.; Granada, L.; Barba, L.; Gutierrez, H.; Pulgarin, C.; Barceló, D. Analysis and toxicity of methomyl and ametryn after biodegradation. Anal. Bioanal. Chem. 2002, 373, 704-709. [CrossRef] [PubMed]

76. Yan, Q.; Hong, Q.; Han, P.; Dong, X.; Shen, Y.; Li, S. Isolation and characterization of a carbofuran-degrading strain Novosphingobium sp. FND-3. FEMS Microbiol. Lett. 2007, 271, 207-213. [CrossRef] [PubMed]

77. Peng, X.; Zhang, J.; Li, Y.; Li, W.; Xu, G.; Yan, Y. Biodegradation of insecticide carbofuran by Paracoccus sp. YM3. J. Environ. Sci. Health B 1997, 43, 588-594. [CrossRef]

78. Omolo, K.M. Characterization of methomyl and carbofuran degrading-bacteria from soils of horticultural farms in Rift Valley and Central Kenya. Afr. J. Environ. Sci. Technol. 2012, 6, 104-114.

79. Tien, C.J.; Lin, M.; Chiu, W.H.; Chen, C. Biodegradation of carbamate pesticides by natural river biofilms in different seasons and their effects on biofilm community structure. Environ. Pollut. 2013, 179, 95-104. [CrossRef]

80. Kulkarni, A.G.; Kaliwal, B.B. Bioremediation of methomyl by soil isolate-Pseudomonas Aeruginosa. J. Environ. Sci. Toxicol. Food Technol. 2014, 8, 1-10. [CrossRef]

81. Ferreira, L.; Rosales, E.; Angeles Sanroman, M.; Pazos, M.M. Scale-up of removal process using a remediating-bacterium isolated from marine coastal sediment. RSC Adv. 2015, 5, 36665-36672. [CrossRef]

82. Castro-Gutiérrez, V.; Masís-Mora, M.; Caminal, G.; Vicent, T.; Carazo-Rojas, E.; Mora-López, M.; Rodríguez-Rodríguez, C.E. A microbial consortium from a biomixture swiftly degrades high concentrations of carbofuran in fluidized-bed reactors. Process Biochem. 2016, 51, 1585-1593. [CrossRef]

83. Konstantina, R.; Eleni, C.; Dafne, G.; Eftychia, S.; Demetra, K.; Panagiotis, K.; Spyridon, N.; Maria, T.; Emmanuel, A.T.; Dimitrios, G.K. Isolation of oxamyl-degrading bacteria and identification of $c e h A$ as a novel oxamyl hydrolase gene. Front. Microbiol. 2016, 7, 616.

84. Roy, T.; Das, N. Isolation, characterization, and identification of two methomyl-degrading bacteria from a pesticide-treated crop field in west Bengal, India. Microbiology 2017, 6, 753-764. [CrossRef]

85. Gong, T.; Xu, X.; Dang, Y.; Kong, A.; Wu, Y.; Liang, P.; Wang, S.; Yu, H.; Xu, P.; Yang, C. An engineered Pseudomonas putida can simultaneously degrade organophosphates, pyrethroids and carbamates. Sci. Total Environ. 2018, 628, 1258-1265. [CrossRef] [PubMed]

86. Kulkarni, A.G.; Kaliwal, B.B. Bioremediation of methomyl by Escherichia coli. In Toxicity and Biodegradation Testing; Humana Press: New York, NY, USA, 2018; pp. 75-86.

87. Roy, T.; Bandopadhyay, A.; Sonawane, P.J.; Majumdar, S.; Mahapatra, N.R.; Alam, S.; Das, N. Bio-effective disease control and plant growth promotion in lentil by two pesticide degrading strains of Bacillus sp. Biol. Control 2018, 127, 55-63. [CrossRef]

88. Kaur, P.; Balomajumder, C. Simultaneous biodegradation of mixture of carbamates by newly isolated Ascochyta sp. CBS 237.37. Ecotoxicol. Environ. Saf. 2019, 169, 590-599. [CrossRef]

89. Wen, X.; Jia, Y.; Li, J. Enzymatic degradation of tetracycline and oxytetracycline by crude manganese peroxidase prepared from Phanerochaete chrysosporium. J. Hazard. Mater. 2010, 177, 924-928. [CrossRef]

90. Harms, H.; Schlosser, D.; Wick, L.Y. Untapped potential: Exploiting fungi in bioremediation of hazardous chemicals. Nat. Rev. Microbiol. 2011, 9, 177-192. [CrossRef]

91. Chen, S.; Liu, C.; Peng, C.; Liu, H.; Hu, M.; Zhong, G. Biodegradation of chlorpyrifos and its hydrolysis product 3, 5, 6-trichloro-2-pyridinol by a new fungal strain Cladosporium cladosporioides Hu-01. PLoS ONE 2012, 7, e47205. [CrossRef]

92. Chen, S.; Hu, Q.; Hu, M.; Luo, J.; Weng, Q.; Lai, K. Isolation and characterization of a fungus able to degrade pyrethroids and 3-phenoxybenzaldehyde. Bioresour. Technol. 2011, 102, 8110-8116. [CrossRef] [PubMed]

93. Chen, A.; Zeng, G.; Chen, G.; Fan, J.; Zou, Z.; Li, H.; Hu, X.; Long, F. Simultaneous cadmium removal and 2,4-dichlorophenol degradation from aqueous solutions by Phanerochaete chrysosporium. Appl. Microbiol. Biotechnol. 2011, 91, 811-821. [CrossRef] [PubMed]

94. Fragoeiro, S.; Magan, N. Impact of Trametes versicolor and Phanerochaete chrysosporium on differential breakdown of pesticide mixtures in soil microcosms at two water potentials and associated respiration and enzyme activity. Int. Biodeterior. Biodegrad. 2008, 62, 376-383. [CrossRef]

95. Liu, X.; Liang, M.; Liu, Y.; Fan, X. Directed evolution and secretory expression of a pyrethroid-hydrolyzing esterase with enhanced catalytic activity and thermostability. Microb. Cell Factories 2017, 16, 81. [CrossRef] [PubMed] 
96. Chen, S.; Hu, M.; Liu, J.; Zhong, G.; Yang, L.; Rizwan-ul-Haq, M.; Han, H. Biodegradation of beta-cypermethrin and 3-phenoxybenzoic acid by a novel Ochrobactrum lupini DG-S-01. J. Hazard. Mater. 2011, 187, 433-440. [CrossRef]

97. Yang, J.; Feng, Y.; Zhan, H.; Liu, J.; Zhang, K.; Zhang, L.H.; Chen, S. Characterization of a pyrethroid-degrading Pseudomonas fulva strain P31 and biochemical degradation pathway of D-phenothrin. Front. Microbiol. 2018, 9, 1003. [CrossRef]

98. Chen, S.; Deng, Y.; Chang, C.; Lee, J.; Cheng, Y.; Cui, Z.; Zhou, J.; He, F.; Hu, M.; Zhang, L.H. Pathway and kinetics of cyhalothrin biodegradation by Bacillus thuringiensis strain ZS-19. Sci. Rep. 2015, 5, 8784. [CrossRef]

99. Chen, S.; Dong, Y.H.; Chang, C.; Deng, Y.; Zhang, X.F.; Zhong, G.; Song, H.; Hu, M.; Zhang, L.H. Characterization of a novel cyfluthrin-degrading bacterial strain Brevibacterium aureum and its biochemical degradation pathway. Bioresour. Technol. 2013, 132, 16-23. [CrossRef]

100. Bhatt, P.; Bhatt, K.; Huang, Y.; Lin, Z.; Chen, S. Esterase is a powerful tool for the biodegradation of pyrethroid insecticides. Chemosphere 2020, 244, 125507. [CrossRef]

101. Zhan, H.; Huang, Y.; Lin, Z.; Bhatt, P.; Chen, S. New insights into the microbial degradation and catalytic mechanism of synthetic pyrethroids. Environ. Res. 2020, 182, 109138. [CrossRef]

102. Nguyen, T.P.O.; Helbling, D.E.; Bers, K.; Fida, T.T.; Wattiez, R.; Kohler, H.E.; Springael, D.; Mot, R.D. Genetic and metabolic analysis of the carbofuran catabolic pathway in Novosphingobium sp. KN65.2. Appl. Microbiol. Biotechnol. 2014, 98, 8235-8252. [CrossRef] [PubMed]

103. Öztürk, B.; Ghequire, M.; Nguyen, T.P.O.; De Mot, R.; Wattiez, R.; Springael, D. Expanded insecticide catabolic activity gained by a single nucleotide substitution in a bacterial carbamate hydrolase gene. Environ. Microbiol. 2016, 18, 4878-4887. [CrossRef] [PubMed]

104. Fareed, A.; Zaffar, H.; Rashid, A.; Maroof Shah, M.; Naqvi, T.A. Biodegradation of N-methylated carbamates by free and immobilized cells of newly isolated strain Enterobacter cloacae strain TA7. Bioremediat. J. 2017, 21, 119-127. [CrossRef]

105. Yang, L.; Chen, S.; Hu, M.; Liu, J. Biodegradation of carbofuran by Pichia anomala strain HQ-C-01 and its application for bioremediation of contaminated soils. Biol. Fert. Soils 2011, 47, 917-923. [CrossRef]

106. Tomasek, P.H.; Karns, J.S. Cloning of a carbofuran hydrolase gene from Achromobacter sp. strain WM111 and its expression in gram-negative bacteria. J. Bacteriol. 1989, 171, 4038-4044. [CrossRef] [PubMed]

107. Desaint, S.; Hartmann, A.; Parekh, N.R.; Fournier, J. Genetic diversity of carbofuran-degrading soil bacteria. FEMS Microbiol. Ecol. 2000, 34, 173-180. [CrossRef]

108. Naqvi, T.; Cheesman, M.J.; Williams, M.R.; Campbell, P.M.; Ahmed, S.; Russell, R.J.; Scott, C.; Oakeshott, J.G. Heterologous expression of the methyl carbamate-degrading hydrolase MCD. J. Biotechnol. 2009, 144, 89-95. [CrossRef]

109. Bhatt, P.; Huang, Y.; Zhang, W.; Sharma, A.; Chen, S. Enhanced cypermethrin degradation kinetics and metabolic pathway in Bacillus thuringiensis strain SG4. Microorganisms 2020, 8, 223. [CrossRef]

(C) 2020 by the authors. Licensee MDPI, Basel, Switzerland. This article is an open access article distributed under the terms and conditions of the Creative Commons Attribution (CC BY) license (http://creativecommons.org/licenses/by/4.0/). 